\title{
A short history of Japanese historical seismology: past and the present
}

\author{
Ritsuko S. Matsu'ura* (1)
}

\begin{abstract}
Since seismicity in Japan is fairly high, Japanese interest in historical seismicity can be traced back to the nineth century, only a few centuries after the formation of the ancient ruling state. A 1000 years later, 2 years earlier than the modern seismological society was founded, the research on historical seismology started in Japan in 1878. By the accumulation for the recent 140 years, the present Japanese seismologists can read many historical materials without reading cursive scripts. We have a convenient access to the historical information related to earthquakes, in the modern characters of 27,759 pages. We now have 214 epicenters of historical earthquakes from 599 AD to 1872. Among them, 134 events in the early modern period were assigned hypocentral depths and proper magnitudes. The intensity data of 8700 places by those events were estimated. These precise intensity data enabled us to compare the detailed source areas of pairs of repeated historical earthquakes, such as the 1703 Genroku earthquake with the 1923 Kanto earthquake, and the 1707 Hoei earthquake with the summation of the 1854 Ansei Tokai and Ansei Nankai earthquakes. It is revealed that the focal area of the former larger event cannot completely include those of the latter smaller earthquakes, although those were believed to be typical sets of characteristic interplate earthquakes at the Sagami trough and at the Nankai trough. Research on historical earthquakes is very important to assess the seismic hazard in the future. We still have one-fifth events of the early modern period to be analyzed in detail. The compilation of places experienced high intensities in the modern events is also necessary. For the ancient and medieval periods, many equivocal events are still left. The further advance of the interdisciplinary research on historical seismology is necessary.
\end{abstract}

Keywords: Japanese historical seismology, Variations in repeated earthquakes, Compiled historical materials, Historical maximum intensity

\section{Introduction}

In and around Japan, one-tenth of earthquakes in the world occur. As average there is one M7 earthquake each year in Japan, we have been suffering frequent earthquake disasters even since ancient time. The first compilation of natural disaster history (Sugawara 892) was done by Michizane Sugawara [845-903], who was the talented government official in the ancient statute system of Japan. He classified all the chronological contents of the six nation history books under various items, such as natural disaster, customs, Buddhism, and penal code. In his compilation, 23 destructive earthquakes were included

*Correspondence: matsuura@adep.or.jp

Association for the Development of Earthquake Prediction, 1-5-18,

Sarugaku-cho, Chiyoda-ku, Tokyo 101-0064, Japan among 632 earthquakes felt in somewhere in Japan for the period from $416 \mathrm{AD}$ to $887 \mathrm{AD}$.

When Japanese modern government started in 1868 , many foreign teachers were invited to Japan, mostly to Tokyo (Fig. 1). It was inevitable that the high seismicity around Tokyo, where a felt earthquake occurs once in a few months at least, made those invited foreign scientists interested in earthquakes. After a moderate destructive earthquake, which was called Yokohama Earthquake (M5.8), occurred near Tokyo in 1880, the world first academic society of earthquake research, Seismological Society of Japan (SSJ), was established in Tokyo by the leadership of John Milne [1850-1913], who came to teach mining technology from Britain, but became a seismologist in Japan. The first president of the society was Ichizo Hattori [1851-1929], who wrote the first modern 


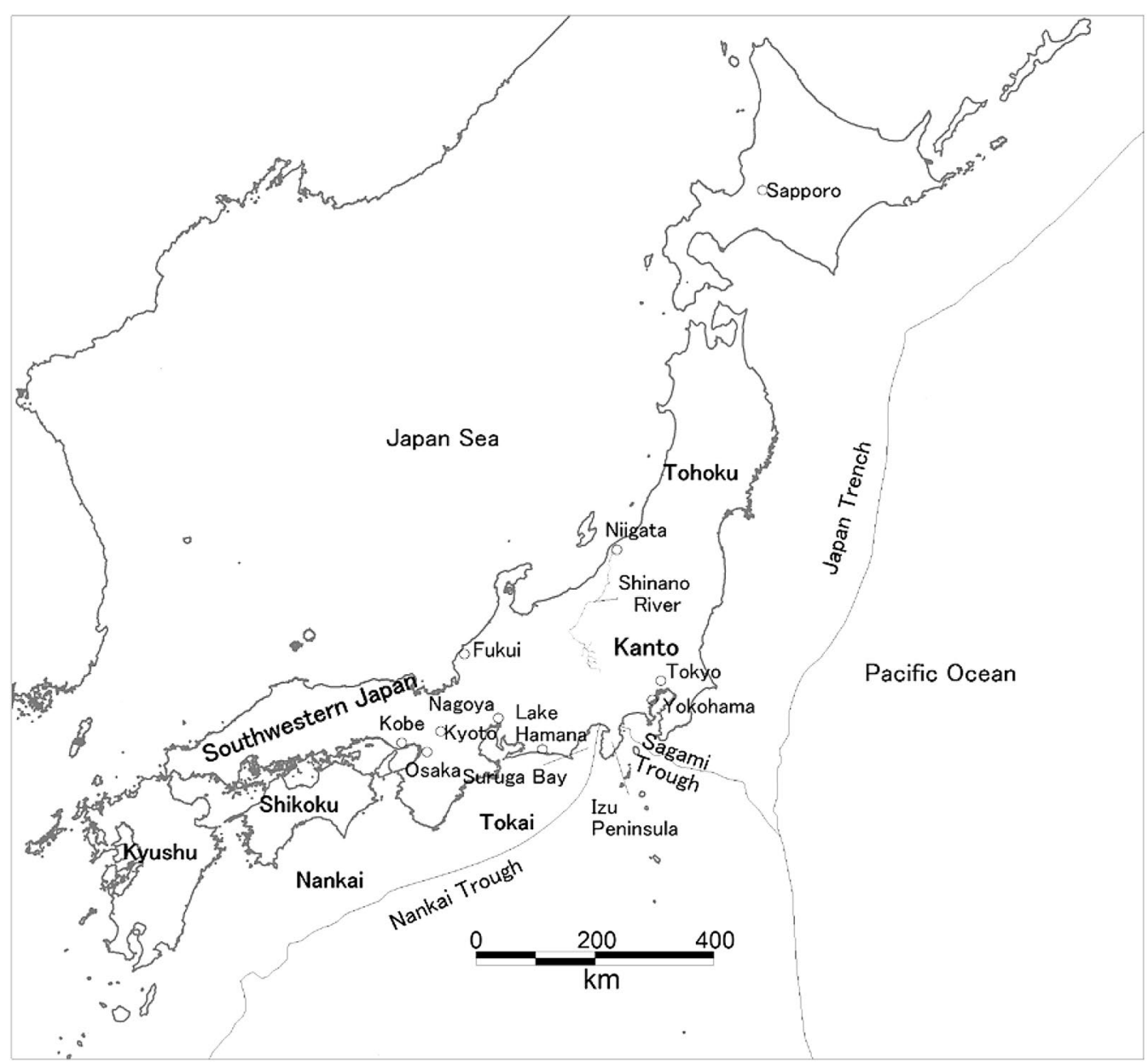

Fig. 1 Place names in and around Japan. Cities, districts, and other places in this paper are shown

paper on historical seismology even before the society was established (Hattori 1878).

In 1891, Nobi earthquake (M8.0) destroyed state-ofthe-art structures at that time such as brick buildings and the railway bridges around Nagoya. Through the effort of Dairoku Kikuchi [1855-1917] and others, the Earthquake Investigation Committee was made in 1892, and the study of historical earthquakes was specified in the second of 18 listed items of the committee business.

Since nineteenth century, modern research on historical seismology has been continued in Japan. The Society of Historical Earthquake Studies was established in 1984, and it is now home to more than 300 members and publishes the scientific journal once a year. Here we briefly review the history of the Japanese historical seismology and the achievement at present.

\section{Before 1923 Kanto earthquake}

The first modern paper of historical seismology (Hattori 1878) was inspired by the discussion of the author with Heinrich Edmund Naumann [1854-1927], who was a German geologist. Since Hattori was educated as a samurai in the early modern period, and then got the Bachelor of Science at Rutgers College in the United States, he could not only read the original historical documents fluently, but also do rudimentary analysis. He listed 149 destructive earthquakes from 34 rather reliable historical materials for the period from 416 AD to 1872 .

At the same time, Naumann also wrote a paper on historical earthquakes in Japan (Naumann 1878). Soon after he arrived to Tokyo in 1875 , he was interested in earthquakes and collected 20 books on earthquakes, which were mostly published in eighteenth and nineteenth 
centuries in Japan. He listed up 213 earthquakes for the period from 416 AD to 1872 . He also estimated damage areas of three large earthquakes, which occurred in the middle of nineteenth century. Since books he used were mostly compiled in the Edo era, it was the matter of course that his list was more contaminated by fakes and duplications than Hattori's. He relied only on secondary materials for the ancient and the medieval period without realizing it. However, the discussion he did on historical seismology in that paper vividly showed his talent as a scientist as much as his papers on geology. After SSJ was founded, Milne $(1881,1882)$ listed 366 earthquakes for the period from $295 \mathrm{BC}$ to $1872 \mathrm{AD}$ from 64 documents. However, his list rather retracted from Hattori's and Naumann's, since he compiled without distinction of myth and fact, or consistency between materials.

Hatasu Ogasima [1857-1892] also made a list of historical earthquakes (Ogashima 1894). He was an engineer of the Bureau of Mines, but his boss sent him to the Bureau of Statistics for the recuperation of his pulmonary tuberculosis. Since the Bureau of Historiography was next to the Bureau of Statistics, he extensively read 213 original historical documents gathered to the Bureau of Historiography by that time, and compiled two books: food history of Japan and the disaster history of Japan. He was the "Sugawara of Meiji era." The early officials of Meiji government like Hattori and Ogashima had the basic cultural training on Chinese and Japanese classics of the early modern period, in addition to the higher education of the West in their adolescence. They had learned necessary abilities for the historical seismology very naturally.

When the Earthquake Investigation Committee was founded in 1892, Minoru Tayama [1865-1907], who was a historian and a staff of the Bureau of Historiography, was assigned to compile historical materials related to earthquakes from documents gathered for the national historiography. He published 1201 pages of historical earthquake records from 465 major historical documents obtained by that time (Tayama 1904). Those letterpress printed pages are decipherable in OCR now. Since Seikei Sekiya [1855-1896], who was the first professor of seismology in the world, superintended Tayama's compilation, he left a list of earthquakes (Sekiya 1899). Sekiya's list was actually finished by Fusakichi Omori [18681923], and contains 1898 felt earthquakes for the period from 416 AD to 1865 . After Tayama finished the compilation, Omori $(1913,1919)$ selected 166 large earthquakes for the period from $416 \mathrm{AD}$ to 1872 , and summarized damage of those major events.

\section{After 1923 Kanto earthquake}

When 1923 Kanto earthquake (M7.9) destroyed Yokohama and Tokyo severely, Kinkichi Musha [1891-1962], who was a high school English teacher and involved in words compilation for English-Japanese dictionary, changed his target of collection from English words to the historical materials related to earthquakes. Since 1928, Torahiko Terada [1878-1935], who was the famous physicist and the essayist, encouraged Musha's effort. Terada was instrumental in the establishment of the Earthquake Research Institute (ERI), and was considered as the affectionate father to young scientists at ERI. After Terada passed away, Akitsune Imamura [1870-1948] sponsored Musha. He mainly compiled information from documents available in the Ueno imperial library in Tokyo, where most historical materials were gathered from former clans' colleges for samurais in the Edo era. He added his compilation to Tayama's, and published them in mimeograph printing. The first volume (Musha 1941) was published before the Pacific War began, and the quality of it was not bad. The print and paper quality of the second and third volumes (Musha 1943a, b) was very poor due to the lack of supplies in Japan, even 2 years before the end of the war. It is often very difficult to interpret even in its original print.

1948 Fukui earthquake (M7.1) caused devastating damage to the Fukui basin. The General Headquarters, the Supreme Commander for the Allied Powers (GHQ) began to pay attention for earthquakes in Japan. Takahasi (1951) estimated the tsunami risk along the Pacific coast of Japan, and Kawasumi (1951) expected the maximum accelerations due to earthquakes for the coming century. To do their studies, the catalogue of historical earthquakes was necessary. GHQ encouraged Musha to publish the historical catalogue of earthquakes. For the first time after Imamura passed away, Musha got the fund to publish the last volume of his compilation in letterpress printing (Musha 1951c). In this volume, Musha added the list of 8953 felt earthquakes and eruptions in Japan and Korea for the period from 2 AD to 1867, and the list of 190 destructive earthquakes in Japan for the period from 599 AD to 1872 . He also published the catalogue of 257 historical earthquakes in and around Japan for the same period, which was left by Imamura, in mimeograph printings (Musha 1950a, b, c, d, e, f, 1951a, b, 1953a, b). Kawasumi (1951) modified that catalogue and used 251 historical earthquakes. He estimated 167 epicenters and 236 magnitudes of his scale (Mk) among those events (Figs. 2, 3). 


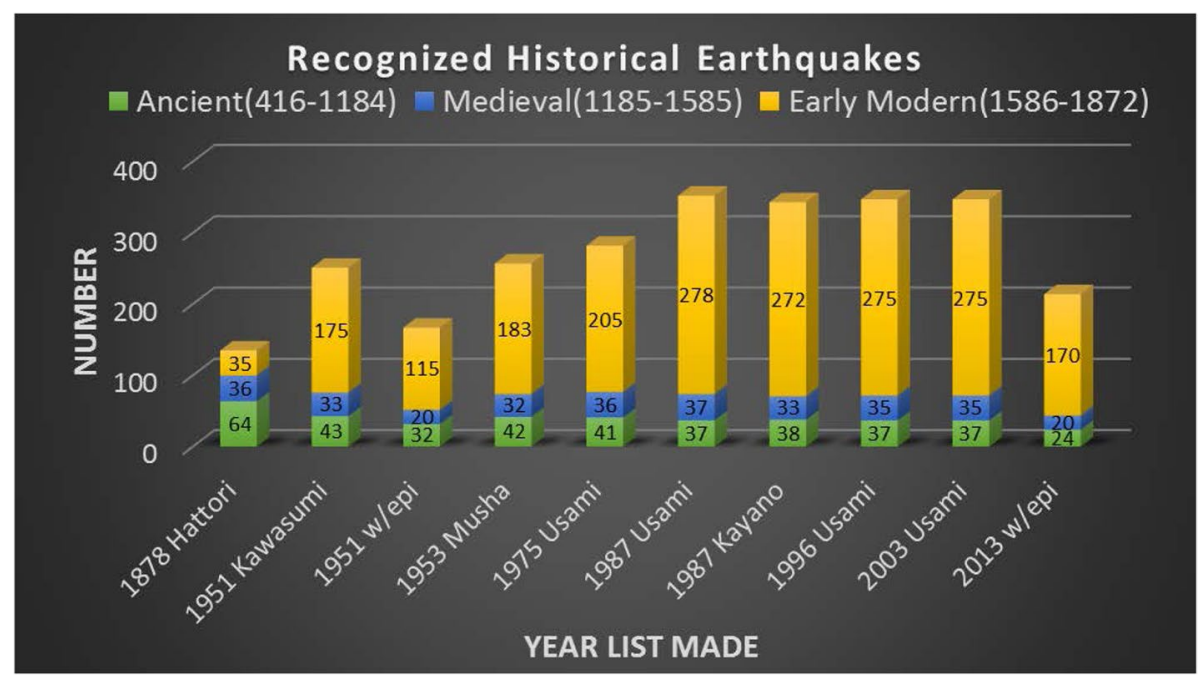

Fig. 2 Number of historical earthquakes listed in each paper. 1951 w/epi and 2013 w/epi show number of earthquakes of which epicenters were estimated in Kawasumi (1951) and Usami et al. (2013), respectively. Each number shows number of events of ancient [416 AD- 1184], medieval [11851585], and early modern [1586-1872] periods, respectively. Politically, early modern period of Japan ended in 1868. However, 1872 is usually used as the last year of historical earthquakes in Japan, because we need the conversion of the lunar calendar to Gregorian calendar by this year. The Meiji government switched to the solar calendar from the lunar calendar in the beginning of 1873

\section{After 1964 Niigata earthquake}

1964 Niigata earthquake (M7.5) destroyed new bridges over the Shinano River including the Showa big bridge, which was completed only 2 weeks before the quake, while Bandai bridge build in 1929 survived. This earthquake not only triggered the foundation of earthquake insurance system for housing in Japan, but also prompted the commencement of the earthquake prediction research program proposed in 1963. In 1965, Japanese program for the earthquake prediction started with a small budget.

In 1976, Katsuhiko Ishibashi [1944-] warned that a large earthquake was impending around the Suruga Bay from the study on 1854 Ansei Tokai earthquake (M8.4) (Ishibashi 1976). His warning pushed up the historical seismology to an important item of the program. For the first time after 70 years since Tayama finished his compilation, the collection business of historical documents on earthquakes began for seismologists with the cooperation of the Historiographical Office of the University of Tokyo. Tatsuo Usami [1924-] of ERI was in charge of it. Although he was a theoretical seismologist, he energetically collected a lot of local documents preserved in old warehouses of former village headmen and large merchants in the early modern period. He published collected materials in letterpress printing (ERI 1981, 1982a, b, 1983a, b, 1984a, b, 1985a, b, 1986a, b, 1987a, b, 1988, 1989a, b, 1993, 1994). He also edited a comprehensive list of Japanese destructive earthquakes once in a decade since 1975 (Usami 1975, 1987, 1996, 2003, 2013; Figs. 2, $3)$. He also continued the compilation and published them in the same form (Usami 1998, 1999, 2002, 2005, 2008, 2012) after his retirement.

The accumulation of compiled historical materials from Tayama (1904) to Usami (2012) is now 27,759 pages in 35 books of printed style. The present Japanese seismologists do not have to struggle reading cursive scripts nor line format characters to survey historical earthquakes. However, we have to go back to the original when the research requires the material criticism.

A large amount of early modern historical materials related to earthquakes enabled Itoko Kitahara [1939-] 


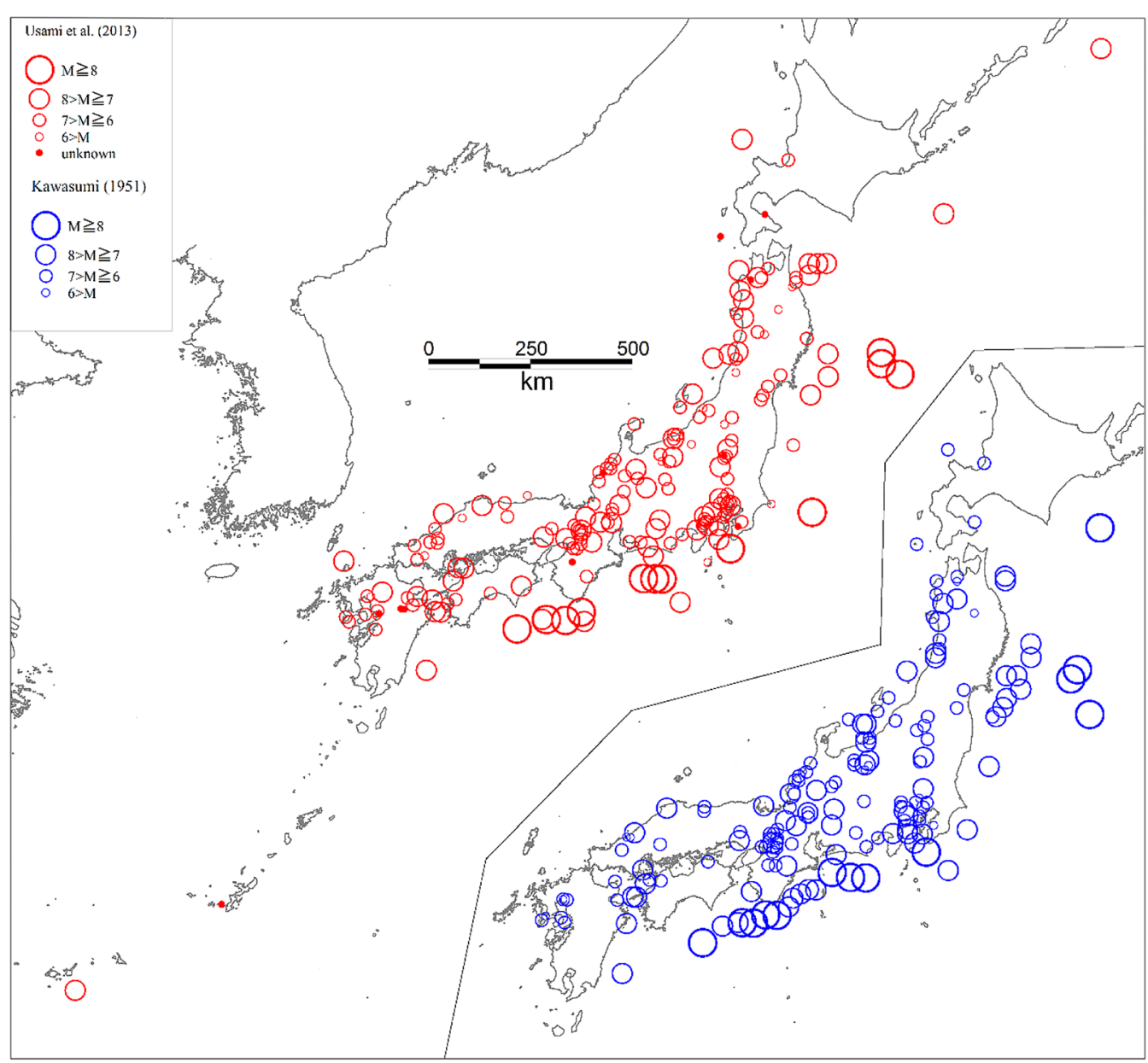

Fig. 3 Epicenter distributions of destructive earthquakes in Japan from 679 AD to 1872 in the latest Usami's list and Kawasumi's list. Red circles are epicenters of 214 events of Usami et al. (2013). Blue circles are epicenters of 167 events in Kawasumi (1951). Mk is transformed to the usual magnitude $(M)$

to establish the disaster history study, which is the humanities research on the social reconstruction process after historical disasters and the impact of disasters to the society. She found that a paradise to survived poor people appeared for a while after a disaster, since their ruler prepared the emergency food and housing in the early modern period (e.g., Kitahara 1983). Ichiro Kayano [1929-2005] embarked analysis of smaller earthquakes with local materials collected by Usami (Kayano 1987). While famous large earthquakes were repeatedly analyzed by various researchers, smaller events were forgotten even by the local society. Local materials allow us to reveal the detail of such a smaller event.

Takahiro Hagiwara [1908-1999] introduced interdisciplinary research for the evolution of historical seismology. He formed a group of experts on history, geology, geography, and engineering in addition to seismology. Material criticisms by historians and checks of vestiges by geologists and geographers were especially effective for some ancient and medieval earthquakes. They revealed that some events are fake. They revised epicenters and magnitudes of some historical earthquakes (e.g., 


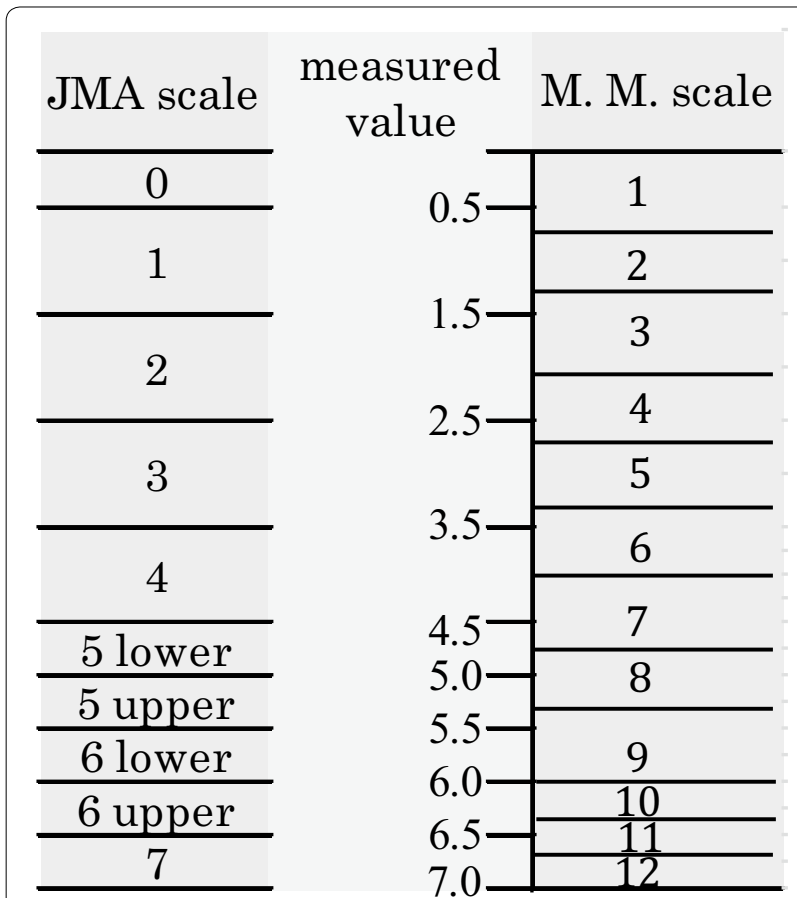

Fig. 4 Relationship between JMA seismic intensity scale and the modified Mercalli intensity scale (modified from Utsu 1966). Measured value in the middle is the output of the seismic intensity meter (e.g., JMA 2016). The output of the seismic intensity meter is up to one decimal place. The detailed explanation of the JMA seismic intensity scale in English is in JMA (2016)

Hagiwara 1982, 1989, 1995). For the ancient and medieval times, Ishibashi (2009) formed the interdisciplinary group of seismologists, volcanologists, historians, and information scientists in 2003 to make recensions of 683 pages of the first volume of Musha's compilation (Musha 1941) and put them in the database available through the web. Although the database has not been completed and does not contain compilations by others, the beta version is now available on the internet.

\section{After 1995 Hanshin-Awaji earthquake disaster}

In 1995, a part of the Mount Rokko active fault group activated, and the M7.3 earthquake caused the devastating disaster in Kobe and neighboring towns. The Headquarter of the Earthquake Research Promotion of Japan
(HERP) was established in the government (now attached to the Ministry of Education, Culture, Sports, Science, and Technology of Japan: MEXT) to evaluate seismic hazard throughout Japan. They started to enhance various seismic and geodetic observations nationwide. Seismic intensities of JMA scale (Fig. 4) are measured nationwide at more than four thousand sites now. Due to the tectonic setting in Japan (Fig. 5), earthquakes of different types occur in and around Japan in various depths. The present dense data of seismic intensities in Japan give us useful information on seismic intensity distributions for earthquakes of known place, type, and depth (Fig. 6). It allows us not only to distinguish the depth and the type of earthquakes, but also to estimate the appropriate magnitude by taking the influence of the structure on the seismic intensity distribution into account.

Historical earthquakes have been only assigned epicenters and magnitudes from simple isoseismal maps. As the part of HERP promotion, we started to analyze historical earthquakes systematically to make a catalogue of hypocenters and magnitudes with the aid of dense data of seismic intensities accumulated after 1995. If we can accurately identify each location of seismic intensities of a historical earthquake left in historical documents, we can estimate the depth and type of that event by comparison with distributions of seismic intensities of the recent similar events. Since 1997, we have been accumulated pin-point seismic intensities for 169 target destructive earthquakes, which occurred from 1586 to 1884 , from the beginning of the early modern period till the start of the modern measurement of seismic intensities by the Meiji government. We have already estimated seismic intensities of 8700 places for 134 earthquakes, which are four-fifths of the target events (Fig. 7). In addition to places, we also revealed damaged areas for many earthquakes. With those data, we estimated magnitudes, epicenters, and depths of 134 events (Fig. 8).

The precise examination of the intensity distributions of some large historical earthquakes revealed the important differences between some interplate major earthquakes, which were believed to be repeating at the same source area, and thought to be typical characteristic earthquakes. The focal area of the 1923 Taisho Kanto earthquake (M7.9: see "Appendix" for the name of Japanese major earthquakes) has been believed to be a western subset of the focal area of the 1703 Genroku 


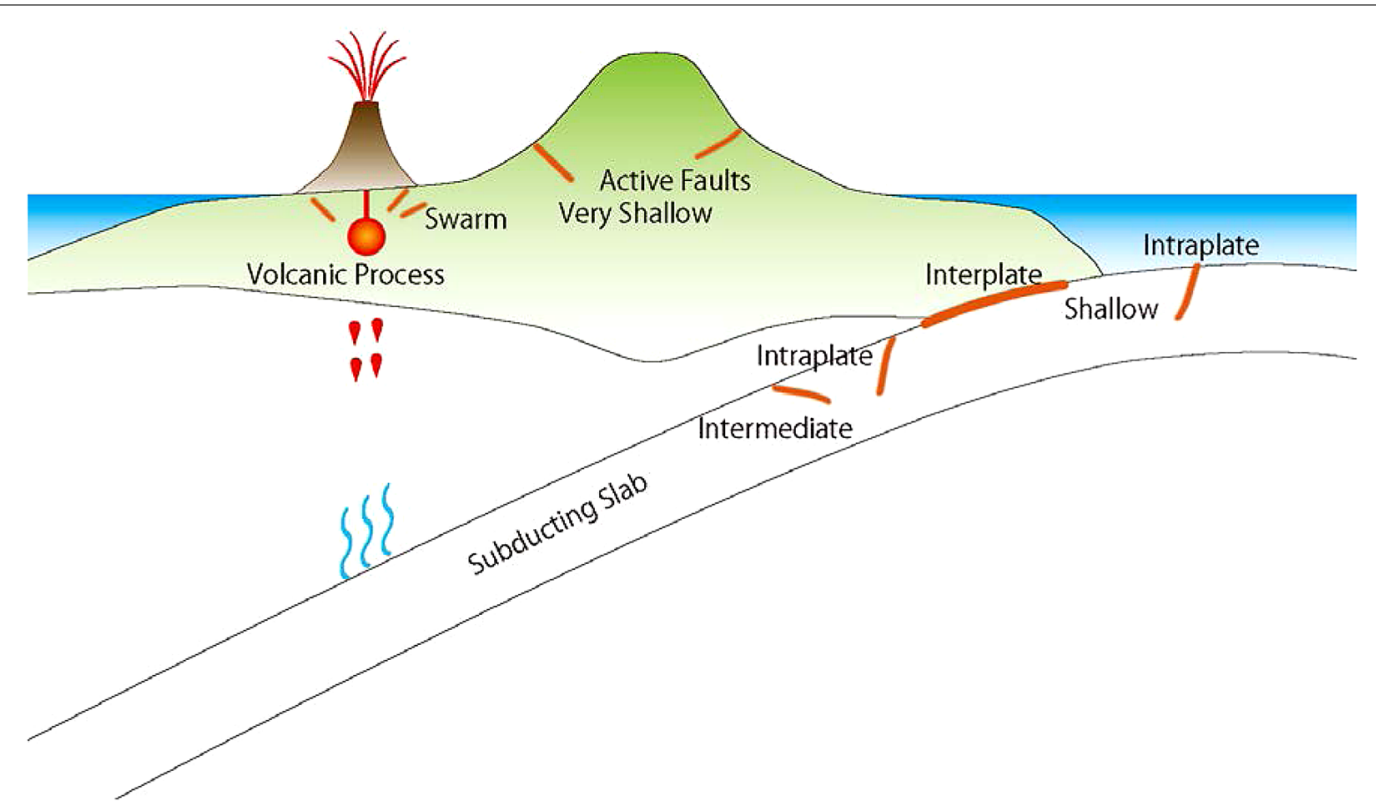

Fig. 5 Various types and depths of earthquakes in and around Japan. Very shallow earthquakes occur at active faults or near the volcanic active areas. At an active fault in Japan, an M7 earthquake occurs about once in a 1000 years to several thousand years. Shallow thrust-type interplate earthquakes occur at plate boundaries along trenches and troughs off the Pacific side of Japan. An M8 earthquake occurs about once in a 100 years to a few hundred years at one section of those. Near the outer rise of the oceanic plate, normal fault-type intraplate earthquakes occur at the shallow depth. Intermediate depth intraplate earthquakes occur in the subducting slab just beneath the Japan Archipelago. Since the stress drop of the intraplate earthquake is larger than that of the interplate earthquake, stronger short period waves are felt in remote sites

earthquake (M8.1). However, the intensities in the southwestern Japan and places in the Izu Peninsula of the 1703 event are smaller than those in 1923. We revealed that the western most part of the 1923 source area did not move in 1703 (Fig. 9; Matsu'ura and Nakamura 2016). The focal area of the 1707 Hoei earthquake (M8.6) has been thought to be the simple summation of focal areas of the 1854 Ansei Tokai (M8.4) and Ansei Nankai (M8.4) earthquakes. However, smaller intensities around the Suruga Bay in addition to smaller intensities of Kanto district in 1707 show that the shaking in those areas is weaker than that in 1854, although the magnitude of the 1707 event is larger (Fig. 10; Matsu'ura et al. 2011a, b). The crustal movements in the regions east from the Lake Hamana, and the southwestern part of Shikoku were also smaller in 1707 than those in 1854 (e.g., Shishikura and Namegaya 2011; Matsu'ura et al. 2011a, b). The west and east ends of the focal area of the 1707 Hoei earthquake are different from both ends of the combined area of two 1854 Ansei earthquakes. Those examples tell us that even such major interplate events occur in not exactly the same source area at each time. Actual focal areas vary by time. We should be very careful to prepare for the next event and should not expect only the same phenomena of some historical events will occur next time.

\section{Discussion}

Figure 2 shows the number of recognized historical earthquakes in Japan for the period from 416 AD to 1872 by each list. For the ancient period, ambiguous events were disappeared by the middle of the twentieth century. For the medieval period, the materials are so rare, and the number of recognized events has not been changed largely. For the early modern period, increase of collected 


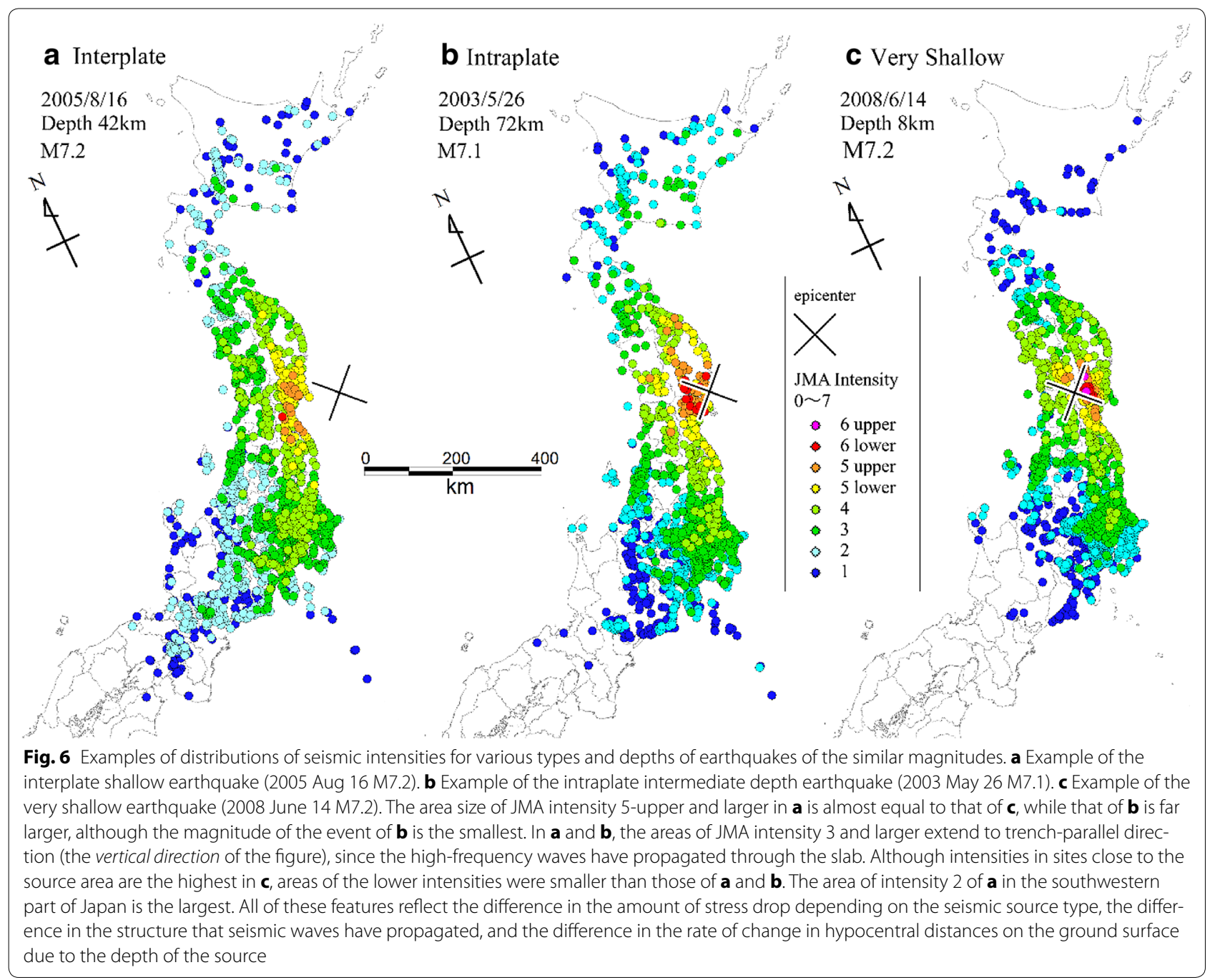

materials resulted in increase of events and epicenters estimated. The comparison of two distributions in Fig. 3 tells that the epicenters of historical earthquakes in the recent list are rather concentrated around the modern known events, and estimated magnitudes are usually smaller than those assigned by Kawasumi.

The early history of Japanese historical seismology overlaps with the history of seismology of the world, since the modern seismology was born in Japan, where many young Occidental scientists felt earthquakes for the first time in their life. The historical seismology in
Japan has been studied mainly by seismologists as science. Because Japanese seismology has been strongly influenced by occasional earthquakes, the research base of historical seismology became stronger or weaker from time to time. After HERP was established in 1995, the dense observation of instrumental seismic intensities was realized. It enabled us to study details of historical earthquakes, when we prepare precise locations of damage and their degrees from the historical documents.

Although we have 35 events left to be analyzed, it is worth to compare the distributions of 8700 intensities in 


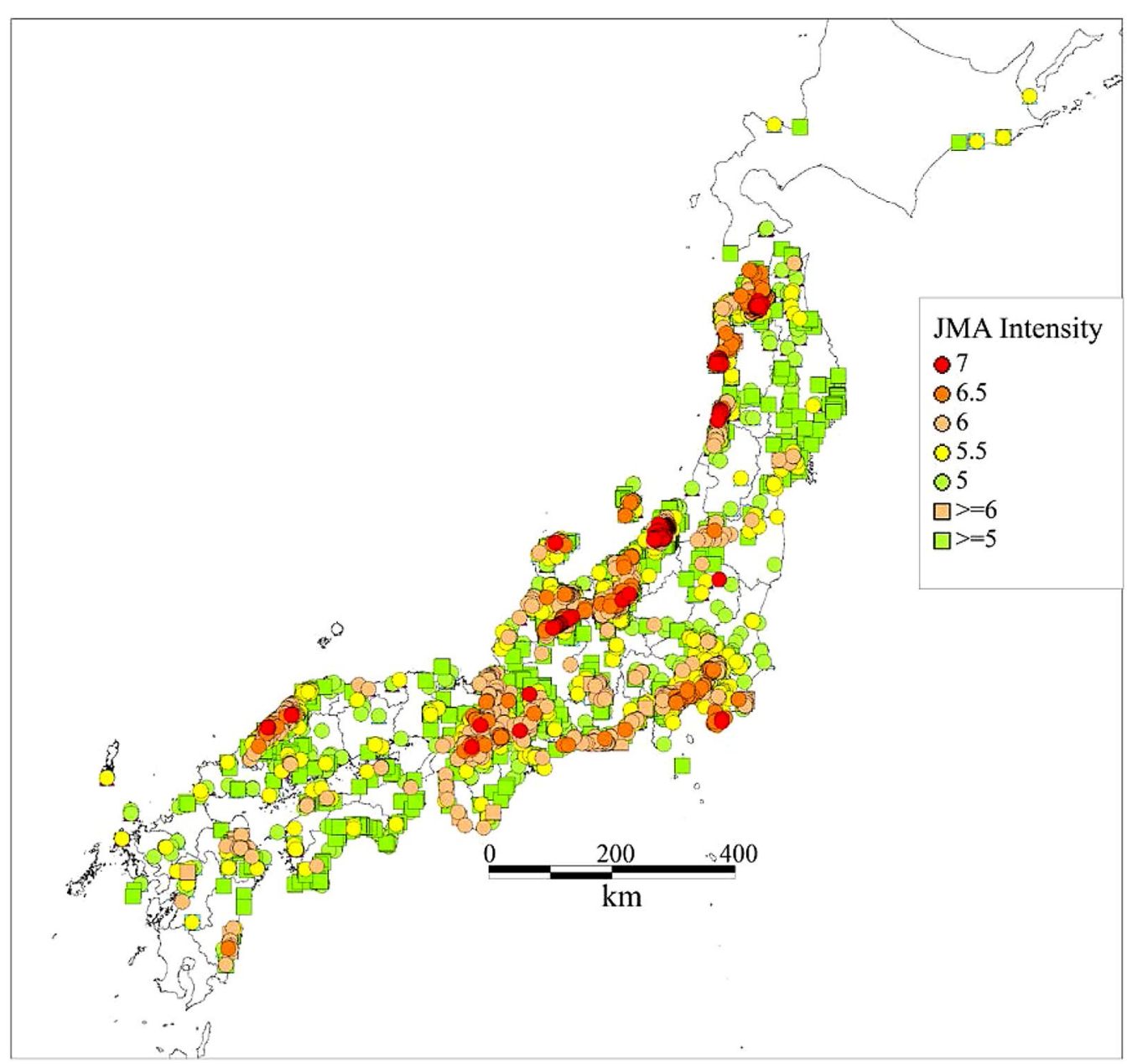

Fig. 7 Estimated seismic intensities of 8700 places for 134 earthquakes in the period from 1586 to 1872. JMA intensity scale (0-7, Fig. 4) is used. Hypocenters of these events are shown in Fig. 8

the early modern period with intensities densely recorded since 1996 April in Japan. Figure 11 shows all places where the JMA intensities of 5 or above were experienced at least once from 1885 till 2016 August. The larger intensity is plotted in the upper layer. From 1885 to 1996 March, intensities were reported only at JMA observatories. In order to compare that term with the distribution plotted in Fig. 7, we need to estimate places experienced high intensities in modern events with the same manner we did for the historical earthquakes. Despite we consider that lack of high intensities in Fig. 11, there are places which experienced the intensity 6 or above after 1885 and not in the period from 1586 to 1884 . In order to assess the maximum intensity of a place within the next several decades, our historical and modern catalogue since 1586 are not enough, since there are fatal earthquakes of a thousand and longer recurrence time such as a very shallow inland earthquake and a gigantic M9 interplate event like the one in 2011 at the area off Tohoku district. We have to include much older historical earthquakes, and activity histories of active faults and huge tsunamis from paleoseismological surveys. 


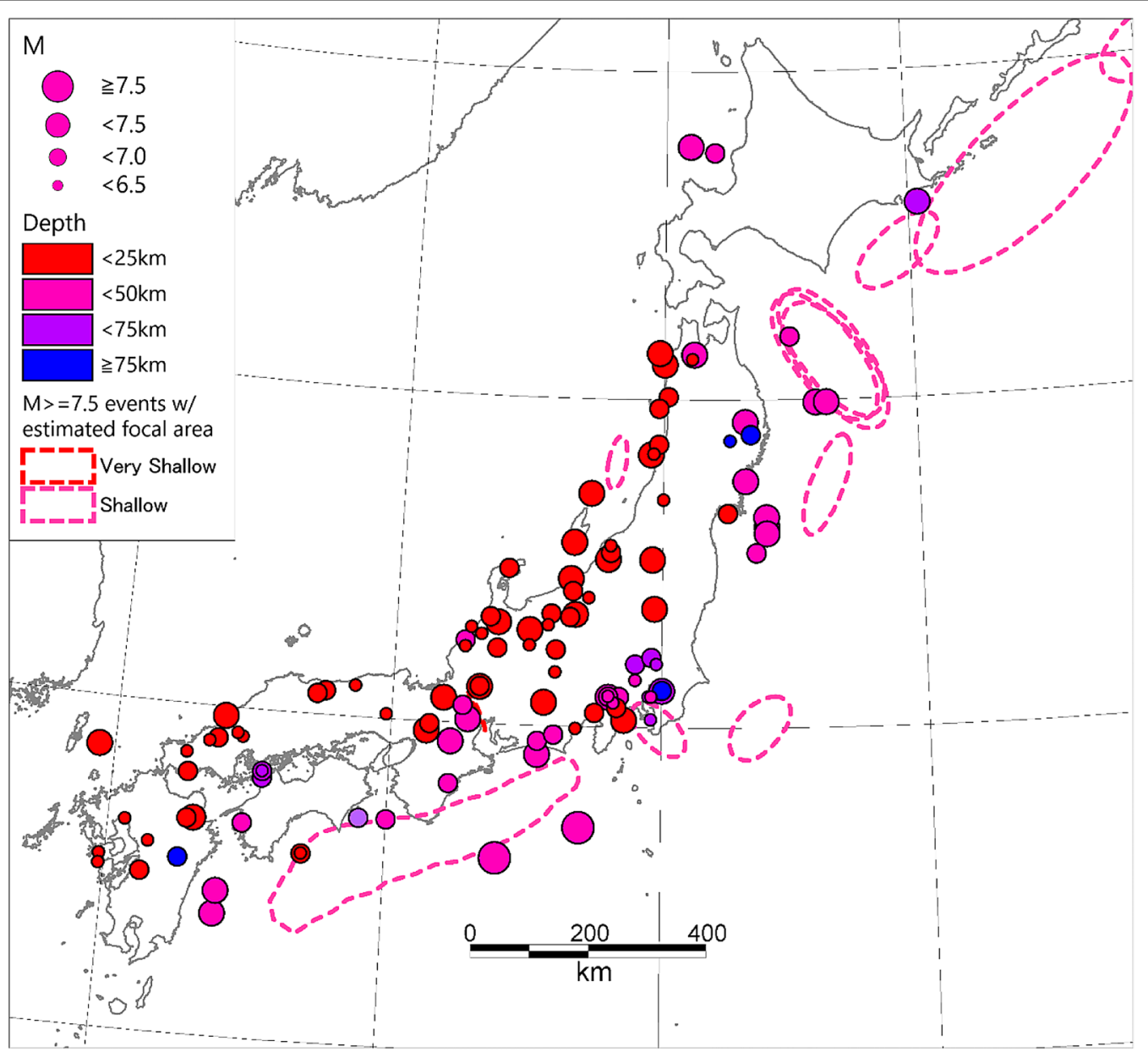

Fig. 8 Hypocenters of 134 examined earthquakes in the period from 1586 to 1872 . For M7.5 or larger events, source regions are shown except for 1605 and 1614 events, of which source areas are unclear and tentative epicenters were shown in the eastern part of the Nankai trough. The symbol size is larger for a larger $\mathrm{M}$. The symbol color is warmer for a shallower event

\section{Conclusions}

Since the seismicity in Japan is really high, Japanese interest in historical seismicity can be traced back to the nineth century. The modern historical seismology started in 1878 here in Japan. Since then, with some weak terms, research bases for historical seismology have been accumulated mainly by seismologists in Japan. Recently, historians who study historical disasters are increasing. We now have the active interdisciplinary society of the historical seismology. Before this century, fake and 


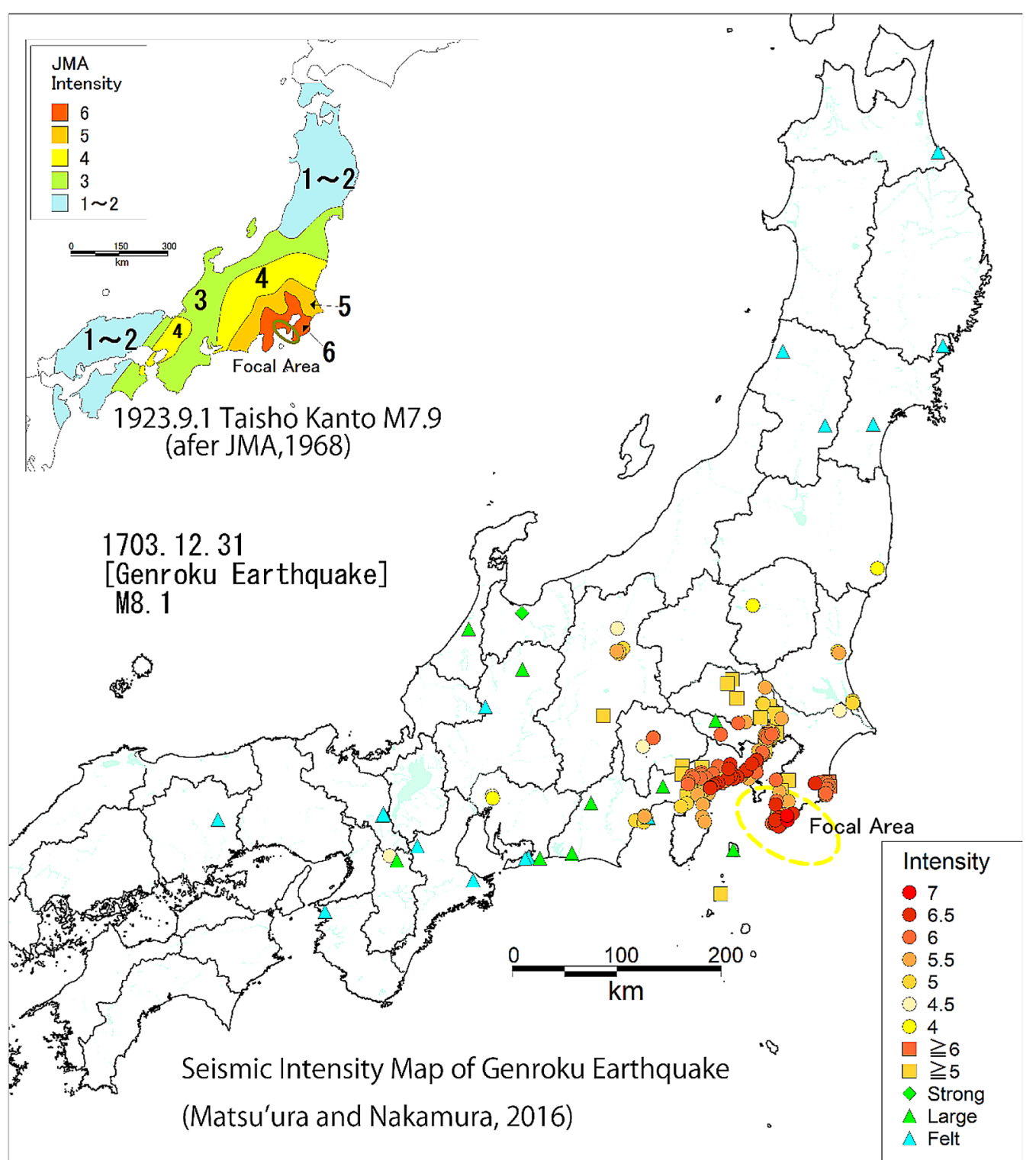

Fig. 9 Intensity distribution of the 1703 Genroku earthquake (M8.1) and the 1923 Taisho Kanto earthquake (M7.9). Both earthquakes occurred along Sagami Trough. Intensities of 1703 after Matsu'ura and Nakamura (2016), and those of 1923 after JMA (1969). Intensities in the west of the Izu Peninsula are apparently smaller than those of 1923. Intensities in areas around Kyoto and Osaka of 1703 are also smaller than those of 1923, even though we consider the difference of the occurrence times of these events. See Fig. 1 and "Appendix" for place and earthquake names

duplication of historical events had been reduced. We have a lot of compilations of historical documents related to earthquakes. We can use the database of historical materials for ancient and medieval periods through the web. We have the epicenter catalogue of historical earthquakes. Japanese seismologists have rather easy approaches to historical seismology. 


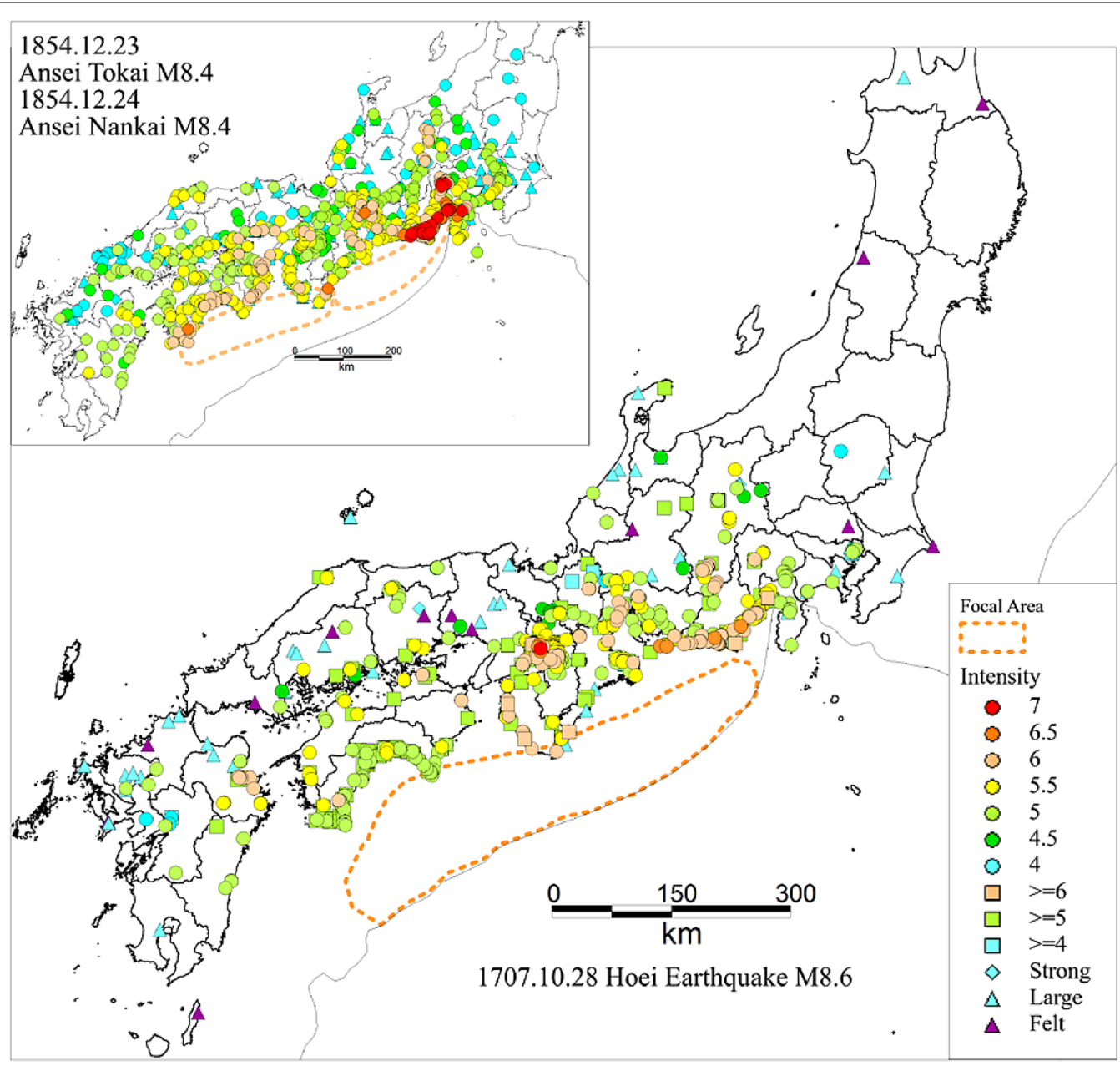

Fig. 10 Intensity distribution of the 1707 Hoei earthquake (M8.6) and the 1854 Ansei Tokai (M8.4) and Ansei Nankai (M8.4) earthquakes. These earthquakes occurred along Nankai Trough. Intensities of 1707 are after Matsu'ura et al. (2011a, b), and those of 1854 are estimated intensities of 4 and larger for regions such as cities and towns (Usami and Daiwa 1994) instead of pin-point places. For 1854, larger intensities of Tokai or Nankai earthquakes are plotted on the upper layer. See Fig. 1 and "Appendix" for place and earthquake names

We also have pin-point intensity data for four-fifths of analyzable events of the early modern period with estimated focal depths and source types. Detailed examination of some early modern events tells that active source areas of the major interplate earthquakes show some variations each time, although they have been believed to be characteristic and repeating. We have to continue the detailed analysis for the remaining one-fifth of the early modern events, in addition to compile places where they experienced high intensities from 1885 to 1996. 


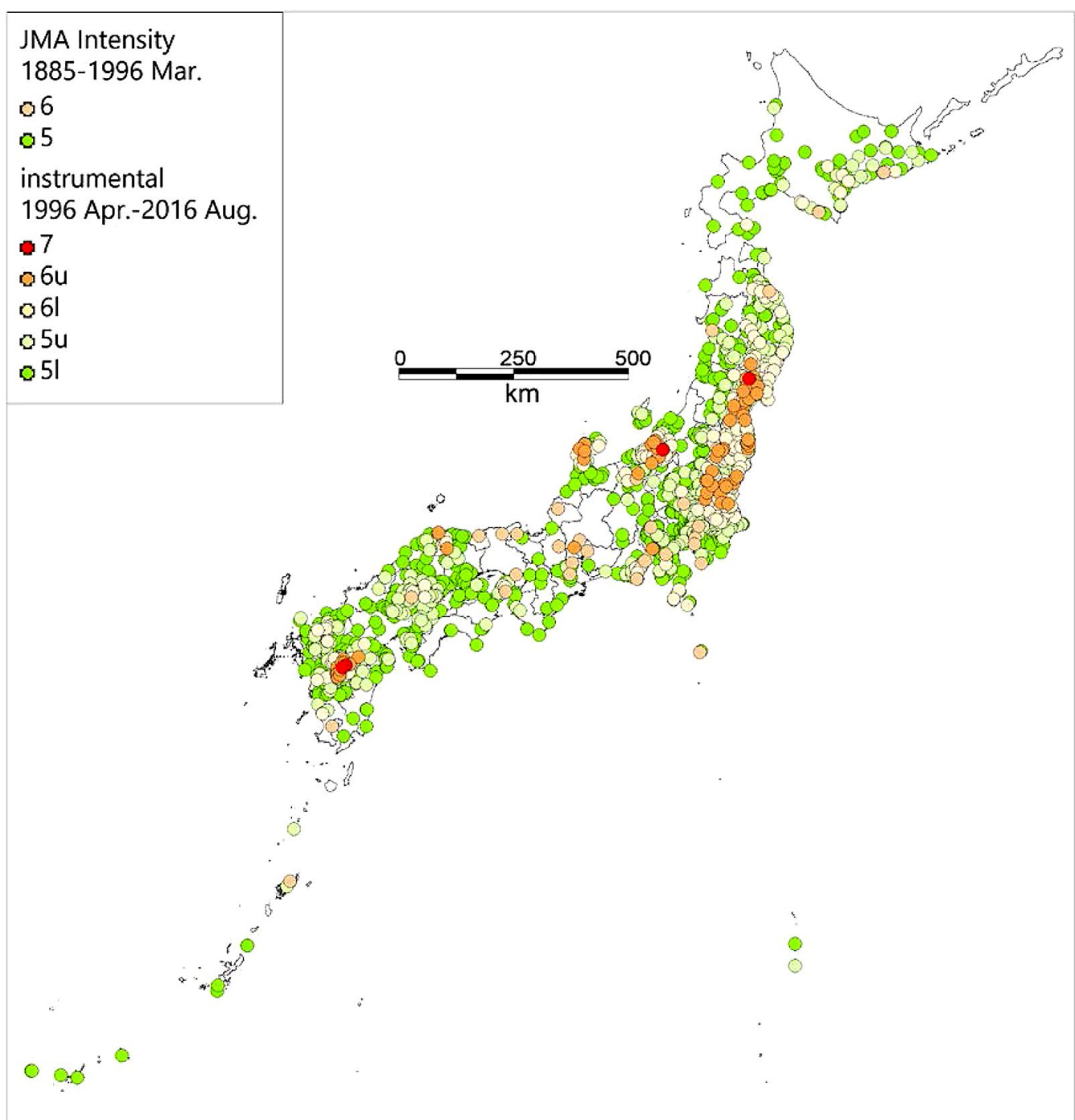

Fig. 11 Observed highest seismic intensities of Japan since 1885 till August 2016. The highest intensities reported at JMA observatories from 1885 to March 1996, and the highest instrumental seismic intensities recorded from April 1996 to August 2016 are shown. The higher intensities are plotted on the upper layer. JMA intensity 7, which is the highest, appears only some places near the source of shallow large earthquakes, and only one place in Tohoku district due to the 2011 off Tohoku district earthquake of M9.0

Historical seismology only can cover recent 1400 years in Japan. We should cope with events with a 1000 years and longer recursive intervals, using paleoseismology in addition to historical seismology.

\section{Abbreviations}

ERI: Earthquake Research Institute, University of Tokyo; GHQ: General Headquarters, the Supreme Commander for the Allied Powers; HERP: The Headquarter of the Earthquake Research Promotion of Japan; JMA: Japan Meteorological Agency; MEXT: The Ministry of Education, Culture, Sports, Science, and Technology of Japan; Mk: Kawasumi's Magnitude; OCR: optical character recognition; SSJ: Seismological Society of Japan.

\section{Acknowledgements}

This study was supported by MEXT, under contracts to support the analysis and evaluation of earthquakes for HERP, the special project on the strain concentrated zone, the priority research on Tachikawa fault, and Scientific research fund \#26330056. Funding was provided by Thematic series on Historical and Geological Studies of Earthquakes.

\section{Competing interests}

The author declares that she has no competing interests.

\section{Funding}

This study was supported by the Ministry of Education, Culture, Sports, Science, and Technology of Japan, under Contracts to support the analysis and evaluation of earthquakes for HERP, the special project on the strain concentrated zone, the priority research on Tachikawa fault, and Scientific research fund \#26330056. 


\section{Appendix}

The name of Japanese major historical earthquakes. Genroku (1688-1704), Hoei (1704-1711), Ansei (18541860), and Taisho (1912-1926) are all names of Japanese era, while Kanto, Tohoku, Tokai, and Nankai are the region names. These names of time and place are usually used as names for major historical earthquakes in Japan. Nankai is the name of the trough off the southwestern Japan (Fig. 1), and Tokai represents the eastern half of the Nankai trough.

Received: 12 October 2016 Accepted: 11 January 2017

Published online: 28 January 2017

\section{References}

Earthquake Research Institute (1981) New collection of historical materials on earthquakes in Japan, vol 1. ERI, Tokyo, pp 193 (in Japanese)

Earthquake Research Institute (1982a) New collection of historical materials on earthquakes in Japan, vol 2. ERI, Tokyo, pp 575 (in Japanese)

Earthquake Research Institute (1982b) New collection of historical materials on earthquakes in Japan, vol S2. ERI, Tokyo, pp 290 (in Japanese)

Earthquake Research Institute (1983a) New collection of historical materials on earthquakes in Japan, vol 3. ERI, Tokyo, pp 961 (in Japanese)

Earthquake Research Institute (1983b) New collection of historical materials on earthquakes in Japan, vol S3. ERI, Tokyo, pp 590 (in Japanese)

Earthquake Research Institute (1984a) New collection of historical materials on earthquakes in Japan, vol 4. ERI, Tokyo, pp 870 (in Japanese)

Earthquake Research Institute (1984b) New collection of historical materials on earthquakes in Japan, vol S4. ERI, Tokyo, pp 582 (in Japanese)

Earthquake Research Institute (1985a) New collection of historical materials on earthquakes in Japan, vol 5. ERI, Tokyo, pp 599 (in Japanese)

Earthquake Research Institute (1985b) New collection of historical materials on earthquakes in Japan, vol S5-1. ERI, Tokyo, pp 403 (in Japanese)

Earthquake Research Institute (1986a) New collection of historical materials on earthquakes in Japan, vol S5-3. ERI, Tokyo, pp 293 (in Japanese)

Earthquake Research Institute (1986b) New collection of historical materials on earthquakes in Japan, vol S5-4. ERI, Tokyo, pp 667 (in Japanese)

Earthquake Research Institute (1987a) New collection of historical materials on earthquakes in Japan, vol S5-2-1\&2. ERI, Tokyo, pp 1931 (in Japanese)

Earthquake Research Institute (1987b) New collection of historical materials on earthquakes in Japan, vol S5-5-1\&2. ERI, Tokyo, pp 2528 (in Japanese)

Earthquake Research Institute (1988) New collection of historical materials on earthquakes in Japan, vol S5-6-1\&2. ERI, Tokyo, pp 1834 (in Japanese)

Earthquake Research Institute (1989a) New collection of historical materials on earthquakes in Japan, Suppl. ERI, Tokyo, pp 1222 (in Japanese)

Earthquake Research Institute (1989b) New collection of historical materials on earthquakes in Japan, Suppl S. ERI, Tokyo, pp 992 (in Japanese)

Earthquake Research Institute (1993) New collection of historical materials on earthquakes in Japan, Add. Suppl. ERI, Tokyo, pp 1043 (in Japanese)

Earthquake Research Institute (1994) New collection of historical materials on earthquakes in Japan, Add. Suppl. S. ERI, Tokyo, pp 1228 (in Japanese)

Hagiwara T (ed) (1982) Paleo earthquakes. Univ. Tokyo Press, Tokyo, p 312 (in Japanese)

Hagiwara T (ed) (1989) Sequel of paleo earthquakes. Univ. Tokyo Press, Tokyo, p 434 (in Japanese)

Hagiwara T (ed) (1995) Quest of paleo earthquakes. Univ. Tokyo Press, Tokyo, p 306 (in Japanese)

Hattori I (1878) Destructive earthquakes in Japan. Trans Asiatic Soc Jpn $6: 249-275$

Ishibashi K (1976) Reappraisal of the major earthquake that is expected in the Tokai region - a large earthquake in Suruga Bay. Proc Seismol Soc Jpn 2:30-34 (in Japanese)
Ishibashi K (2009) Full-text databasing of historical earthquake documents, Zisin, 61, S509-517 (in Japanese). Database URL is http://sakuya. ed.shizuoka.ac.jp/erice/. Accessed 18 Aug 2016

JMA (1969) Seismic observation guidelines (references). JMA, Tokyo, p 245 (in Japanese)

JMA (2016) Tables explaining the JMA Seismic Intensity Scale. http://www.jma. go.jp/jma/en/Activities/inttable.html. Accessed 27 Dec 2016

Kawasumi H (1951) Measures of earthquake danger and expectancy of maximum intensity throughout Japan as inferred from the seismic activity in historical times. Bull Earthq Res Inst 29:469-482

Kayano I (1987) List of major earthquakes in Japan Part 1. In: Utsu T et al (eds) Encyclopedia of earthquake. Asakura Publishing, Tokyo, pp 467-501 (in Japanese)

Kitahara I (1983) Ansei large earthquake and people-Social history of earthquakes. San-ichi Publishing, Tokyo, p 264 (in Japanese)

Matsu'ura RS, Nakamura M (2016) An innovative fact on the focal area of 1703 Genroku earthquake from the detailed examination of seismic intensities. Hist Seismol 31:9-16 (in Japanese)

Matsu'ura RS, Nakamura M, Karakama I (2011a) A new focal area of 1707 Hoei earthquake from the detailed examination of seismic intensities. Hist Seismol. 26:89-90 (in Japanese)

Matsu'ura RS, Nakamura M, Matsuda T (2011b) On the crustal deformation after the 1707 Hoei earthquake. In: Proc Seismol Soc Jpn Fall 2011, D1108, p 120 (in Japanese)

Milne J (1881) Notes on the great earthquakes of Japan. Trans Seismol Soc Jpn 3:65-102

Milne J (1882) The distribution of seismic activity in Japan. Trans Seismol Soc Jpn 4:1-30

Musha K (1941) Enlarged and revised edition of historical documents on earthquakes in great Japan 1. Ministry of Education, Tokyo, pp 945 (in Japanese)

Musha K (1943a) Enlarged and revised edition of historical documents on earthquakes in great Japan 2. Ministry of Education, Tokyo, pp 754 (in Japanese)

Musha K (1943b) Enlarged and revised edition of historical documents on earthquakes in great Japan 3. Ministry of Education, Tokyo, pp 933 (in Japanese)

Musha K (1950a) Chronological list of large earthquakes in and around Japan. Assoc Earthq Disaster Prev 9:1-19 (in Japanese)

Musha K (1950b) Chronological list of large earthquakes in and around Japan. Assoc Earthq Disaster Prev 10:20-51 (in Japanese)

Musha K (1950c) Chronological list of large earthquakes in and around Japan. Assoc Earthq Disaster Prev 11:52-83 (in Japanese)

Musha K (1950d) Chronological list of large earthquakes in and around Japan. Assoc Earthq Disaster Prev 12:84-115 (in Japanese)

Musha K (1950e) Chronological list of large earthquakes in and around Japan. Assoc Earthq Disaster Prev 13:116-1147 (in Japanese)

Musha K (1950f) Chronological list of large earthquakes in and around Japan. Assoc Earthq Disaster Prev 14:148-179 (in Japanese)

Musha K (1951a) Chronological list of large earthquakes in and around Japan. Assoc Earthq Disaster Prev 15:180-203 (in Japanese)

Musha K (1951b) Chronological list of large earthquakes in and around Japan. Assoc Earthq Disaster Prev 16:204-236 (in Japanese)

Musha K (1951c) Historical documents on earthquakes in Japan. Mainichi Newspapers, Tokyo, pp 757 (in Japanese)

Musha K (1953a) Chronological list of large earthquakes in and around Japan. Assoc Earthq Disaster Prev 17:237-266 (in Japanese)

Musha K (1953b) Chronological list of large earthquakes in and around Japan. Assoc Earthq Disaster Prev 18:267-298 (in Japanese)

Naumann E (1878) Über erdbeben und vulcanausbrüche in Japan. Mitteilungen der Deutschen Gesellschaft für Natur-und Völkerkunde Ostasiens 2(15):163-216 (in German)

Ogashima H (1894) Japanese history of disaster and extraordinary. Mining Institute of Japan, Tokyo, pp 845 (in Japanese)

Omori F (1913) Overview of large earthquakes of Japan. Rep Earthq Inv. Com 68B:1-180 (in Japanese)

Omori F (1919) Summary list of large earthquakes of Japan. Rep Earthq Inv Com 88B:1-71 (in Japanese)

Sekiya S (1899) The earthquake investigation committee catalogue of Japanese earthquakes. J Coll Sci Imp Univ Tokyo 11:315-388 
Shishikura M, Namegaya Y (2011) Crustal movement at the Ashizuri point due to Hoei, Ansei, and Showa Nankai earthquakes. Hist Seismol 26:88 (in Japanese)

Sugawara M (892) Earthquakes, Ruiju Kokushi Vol. 171, Disaster 5. Japanese Goverment (in Japanese)

Takahasi R (1951) An estimate of future tsunami damage along the Pacific coast of Japan. Bull Earthq Res Inst 29:71-95

Tayama M (1904) Historical documents on earthquakes in great Japan. Rep Earthq Inv Com, 46A, 1-606, B, 1-640 (in Japanese)

Usami T (1975) Materials for comprehensive list of Japanese destructive earthquakes. Univ Tokyo Press, Tokyo, p 327 (in Japanese)

Usami T (1987) Materials for comprehensive list of Japanese destructive earthquakes [New edition]. Univ Tokyo Press, Tokyo, p 434 (in Japanese)

Usami T (1996) Materials for comprehensive list of Japanese destructive earthquakes [Revised and enlarged edition] 416-1995. Univ Tokyo Press, Tokyo, p 493 (in Japanese)

Usami T (1998) Addendum of historical documents on earthquakes in Japan, 1. Japan Electric Association, Tokyo, pp 512 (in Japanese)

Usami T (1999) Addendum of historical documents on earthquakes in Japan, S. Japan Electric Association, Tokyo, pp 1045 (in Japanese)

Usami T (2002) Addendum of historical documents on earthquakes in Japan, 2, T. Usami, Tokyo, pp 583 (in Japanese)
Usami T (2003) Materials for comprehensive list of Japanese destructive earthquakes [Latest Edition] [416]-2001. Univ Tokyo Press, Tokyo, p 605 (in Japanese)

Usami T (2005) Addendum of historical documents on earthquakes in Japan, 3, T. Usami, Tokyo, pp 814 (in Japanese)

Usami T (2008) Addendum of historical documents on earthquakes in Japan, 4-1\&2, T. Tokyo, Usami, p 1874 (in Japanese)

Usami T (2012) Addendum of historical documents on earthquakes in Japan, 5-1\&2, T. Usami, Tokyo, pp 1526 (in Japanese)

Usami T, Daiwa Exploration and Consulting Co. Ltd. (1994) Intensity distribution and isoseismal maps of historical earthquakes in Japan. Japan Electric Association, Tokyo, pp 647

Usami T, Ishii H, Imamura T, Takemura M, Matsu'ura RS (2013) Materials for comprehensive list of Japanese destructive earthquakes 599-2012 [Revised 2013]. Univ Tokyo Press, Tokyo, p 694 (in Japanese)

Utsu T (1966) Regional differences in absorption of seismic waves in the upper mantle as inferred from abnormal distributions of seismic intensities. J Fac Sci Hokkaido Univ Ser 7(2):359-374

\section{Submit your manuscript to a SpringerOpen ${ }^{\circ}$ journal and benefit from:}

- Convenient online submission

- Rigorous peer review

- Immediate publication on acceptance

- Open access: articles freely available online

- High visibility within the field

- Retaining the copyright to your article 